\title{
Fluorescent-BOX-PCR for resolving bacterial genetic diversity, endemism and biogeography
}

\author{
Lorenzo Brusetti ${ }^{1}$, Iana Malkhazova ${ }^{2}$, Maher Gtari ${ }^{3}$, Isabella Tamagnini ${ }^{1}$, \\ Sara Borin ${ }^{1}$, Maya Merabishvili ${ }^{2}$, Nina Chanishvili ${ }^{2}$, Diego Mora ${ }^{1}$, \\ Francesca Cappitelli ${ }^{1}$ and Daniele Daffonchio*1
}

Address: ${ }^{1}$ Dipartimento di Scienze e Tecnologie Alimentari e Microbiologiche (DISTAM), Università degli Studi di Milano, via Celoria 2, 20133, Milan, Italy, ${ }^{2} \mathrm{G}$. Eliava Institute of Bacteriophage, Microbiology and Virology (IBMV) Gotua Street 3, 0160, Tbilisi, Georgia and ${ }^{3}$ Laboratoire Microrganismes et Biomolécules Actives, Département de Biologie, Faculté des Sciences de Tunis, Campus Universitaire, 20092 Tunis, Tunisie

Email: Lorenzo Brusetti - lorenzo.brusetti@unimi.it; Iana Malkhazova - ianka_m@mail.ru; Maher Gtari - maher.gtari@fst.rnu.tn; Isabella Tamagnini - isabella.tamagnini@unimi.it; Sara Borin - sara.borin@unimi.it; Maya Merabishvili - m_merabish.ibmv@caucasus.net; Nina Chanishvili -n_chanish.ibmv@caucasus.net; Diego Mora - diego.mora@unimi.it; Francesca Cappitelli - francesca.cappitelli@unimi.it; Daniele Daffonchio* - daniele.daffonchio@unimi.it

* Corresponding author

Published: 15 December 2008

BMC Microbiology 2008, 8:220 doi:10.1 |86/|47|-2180-8-220
Received: 30 May 2008

Accepted: 15 December 2008

This article is available from: http://www.biomedcentral.com/I47I-2180/8/220

(C) 2008 Brusetti et al; licensee BioMed Central Ltd.

This is an Open Access article distributed under the terms of the Creative Commons Attribution License (http://creativecommons.org/licenses/by/2.0), which permits unrestricted use, distribution, and reproduction in any medium, provided the original work is properly cited.

\begin{abstract}
Background: BOX-AIR-based repetitive extragenic palindromic-PCR (BOX-PCR) is one of the most used techniques in biogeography studies of microbial isolates. However the traditional separation of BOX-PCR patterns by agarose gel electrophoresis suffers many limitations. The aim of this research was to set up a fluorescent BOX-PCR (F-BOX-PCR) assay in which separation of $P C R$ products is automated in a capillary electrophoresis system. F-BOX-PCR was compared with the traditional BOX-PCR using bacterial strains with different $G+C$ content (Bacillus cereus; Escherichia coli; isolates of the family Geodermatophilaceae). Resolution, discriminatory power and reproducibility were evaluated by assaying different electrophoretic runs, PCR reactions and independent DNA extractions. BOX-PCR and F-BOX-PCR were compared for the analysis of 29 strains of Modestobacter multiseptatus isolated from three different microsites in an altered carbonatic wall from Cagliari, Italy, and 45 strains of Streptococcus thermophilus isolated from 34 samples of the hand-made, yogurt-like product Matsoni, collected in different locations in Georgia.

Results: Fluorophore 6-FAM proved more informative than HEX and BOX-PCR both in agarose gel electrophoresis $(p<0.004$ and $p<0.00003)$ and in capillary electrophoresis (compared only with HEX, $\left.p<2 \times 10^{-7}\right)$. 6-FAM- and HEX-based F-BOX-PCR respectively detected up to 12.0 and II.3 times more fragments than BOX-PCR. Replicate separations of F-BOX-PCR showed an accuracy of the size calling of \pm 0.5 bp until $500 \mathrm{bp}$, constantly decreasing to $\pm 10 \mathrm{bp}$ at $2000 \mathrm{bp}$. Cluster analysis of F-BOX-PCR profiles grouped $M$. multiseptatus strains according to the microsite of isolation and S. thermophilus strains according to the geographical origin of Matsoni, but resulted intermixed when a BOX-PCR dataset was used.
\end{abstract}

Conclusion: F-BOX-PCR represents an improved method for addressing bacterial biogeography studies both in term of sensitivity, reproducibility and data analysis. 


\section{Background}

Typing by DNA fingerprinting is a common tool used in bacterial biogeography and epidemiology studies. Several bacterial species can be differentiated in clonal lines associated to specific animal hosts [1]. Single genetic differences between clonal lineages could be useful to determine the history of an infection or to find new possible borderline strains [2]. Similarly, fingerprinting methods are frequently used to evaluate the global dispersal of environmentally relevant microbial species or lineages in a species [3], to correlate specific genotypes to a given environmental conditions [4] and to evaluate the endemicity of a given microbial type $[5,6]$.

Different DNA-based typing methodologies are now available and BOX-PCR is the most commonly used technique due to its simplicity, efficiency and low cost. This is a particular version of repetitive extragenic palindromicPCR (rep-PCR) [7] that uses the BOX-A1R primer [8]. BOX-PCR is a fingerprinting analysis based on the BOX dispersed-repeat motif, firstly identified in Streptococcus pneumoniae, but common in a number of bacterial species [9-11]. Since the BOX repetitive sequences are interspersed throughout the genome, BOX-PCR is a method potentially capable of simultaneously surveying many DNA regions scattered in the bacterial genome. It has been shown to have similar or even better strain differentiation power, as well as to be easier to perform, than ribosomal intergenic spacer analysis (RISA), restriction fragment length polymorphism (RFLP), amplified fragment length polymorphism (AFLP), random amplified polymorphic DNA (RAPD) and other techniques [12-14]. BOX-PCR is quicker, cheaper, and in many cases more discriminatory than pulsed field gel electrophoresis (PFGE) [14], despite is generally less reproducible. BOX-PCR patterns are not affected by the culture age of the strain to be analyzed [15] and fingerprinting output can be easily analyzed by computer assisted methods [16]. These features make BOXPCR a frequently used tool in biogeography studies in environmental microbiology [5,17-20].

The current BOX-PCR technique, in which the amplified products are separated by agarose gel electrophoresis, suffers from several limitations like poor band resolution and run standardization for comparison of the different profiles in different gels. To overcome these limitations separation of fluorescent labelled products in automated DNA sequencer can be used [21], but this interesting improvement has been applied rarely in environmental analysis and limited to machines performing separation in long polyacrylamide gels $[21,22]$.

In this study we show that fluorescent BOX-PCR (F-BOXPCR), in which the separation of PCR products is performed in an Abi-Prism 310 capillary electrophoresis sys- tem, is capable of resolving endemicity and the biogeographical repartition of different bacterial populations. We first assessed suitability and reproducibility of different electrophoretic runs of different F-BOX-PCR reactions prepared from independent extractions of DNA from eight bacterial strains exhibiting different $\mathrm{G}+\mathrm{C}$ content. The power of F-BOX-PCR in resolving bacterial endemicity was assessed on a collection of Modestobacter multiseptatus strains isolated from three different microsites of an altered ancient carbonatic wall in the old city of Cagliari, Sardinia, Italy [23]. Biogeographic segregation of different bacterial populations was tested on a collection of 45 strains of Streptococcus thermophilus isolated from the Caucasian home-made yogurt-like product Matsoni produced in different areas of the Georgian Caucasus [24].

\section{Results and discussion Reproducibility of BOX-PCR and F-BOX-PCR in agarose gels}

The reproducibility of BOX-PCR and F-BOX-PCR in agarose gels was analyzed using strains belonging to different taxa with very diverse $\mathrm{G}+\mathrm{C}$ content. We chose six strains of Geodermatophilaceae ( $\mathrm{G}+\mathrm{C}$ content, about 70\%) belonging the genera Blastococcus and Modestobacter, one strain of $E$. coli $(50 \%)$ and one strain of B. cereus $(35 \%)$. The six strains of Geodermatophilaceae were chosen on the basis of their BOX-PCR patterns in agarose gel that should cover a wide size range. Strain DS3 had a BOX-PCR pattern with a relatively small range of fragment length between 300 and 800 bp. Strains CI1-23 and CO2-33 showed BOXPCR patterns with a wider range of fragment length, between 300 and about 2500 bp and between 300 and about 3000 bp respectively. Strains CI2-13, CI2-17 and CI2-23 were also analyzed since they had very similar patterns.

The average number of fragments found with BOX-PCR varied between 6.3 (B. cereus) and 16.6 (E. coli) with relatively high standard deviations (SD) between 0.9 and 4.0 (average SD $=2.2$ ). Number of bands could be variable among replicates from independent DNA extractions, PCR or agarose gels: for example, B. cereus BOX-PCR patterns were represented by 3 to 10 fragments, strain CI2-17 pattern varied between 9 and 18 fragments, while E. coli pattern showed 14 to 19 bands.

Reproducibility of BOX-PCR profiles, obtained from different DNA extractions and different runs in agarose gels, is shown in Table 1 and it is expressed as Jaccard's similarity coefficient between replicates. Examples of BOX-PCR profiles are shown in Figure 1. Reproducibility of results with standard BOX-PCR was affected by DNA extraction $(86.2 \pm 5.7 \%$ of similarity), PCR amplification $(78.0 \pm$ $16.1 \%)$ and gel separation $(83.7 \pm 9.0 \%)$. The overall similarity calculated for all replicates was of $62.7 \pm 20.5 \%$. 
Table I: Reproducibility of F-BOX-PCR analysis with HEX and 6-FAM dyes calculated as values of Jaccard's coefficient, in comparison with standard BOX-PCR with separation in agarose gel.

\begin{tabular}{|c|c|c|c|c|c|c|c|c|c|c|c|c|}
\hline \multirow[t]{2}{*}{ Strain } & \multicolumn{4}{|l|}{ Agarose gel } & \multicolumn{4}{|c|}{ HEX-F-BOX } & \multicolumn{4}{|c|}{ 6-FAM-F-BOX } \\
\hline & $\begin{array}{l}\text { DNA } \\
\text { extraction }\end{array}$ & PCR & Gel & Overall & $\begin{array}{l}\text { DNA } \\
\text { extraction }\end{array}$ & PCR & Injection & Overall & $\begin{array}{l}\text { DNA } \\
\text { extraction }\end{array}$ & PCR & Injection & Overall \\
\hline $\begin{array}{l}\text { B. cereus } \\
\text { BC } 360\end{array}$ & 0.822 & 0.554 & 0.651 & 0.300 & 0.985 & 0.985 & 1.000 & 0.971 & 1.000 & 1.000 & 1.000 & 1.000 \\
\hline CII-23 & n.d. ${ }^{a}$ & 0.906 & 0.906 & 0.812 & n.d. & n.d. & n.d. & n.d. & n.d. & 0.972 & 0.972 & 0.972 \\
\hline $\mathrm{Cl} 2-13$ & 0.864 & 0.952 & 0.952 & 0.818 & n.d. & 0.838 & 0.983 & 0.823 & 0.970 & 0.994 & 0.994 & 0.951 \\
\hline $\mathrm{Cl} 2-17$ & n.d. & 0.624 & 0.811 & 0.500 & n.d. & 0.944 & 0.981 & 0.926 & n.d. & 0.961 & 0.980 & 0.942 \\
\hline $\mathrm{Cl} 2-23$ & 0.907 & 0.905 & 0.864 & 0.727 & 0.961 & 0.983 & 0.994 & 0.933 & 0.969 & 0.969 & 1.000 & 0.939 \\
\hline $\mathrm{CO} 2-33$ & n.d. & 0.830 & 0.826 & 0.750 & n.d. & n.d. & n.d. & n.d. & n.d. & 0.978 & 1.000 & 0.978 \\
\hline DS3 & 0.791 & 0.597 & 0.803 & 0.375 & 0.971 & 0.971 & 0.990 & 0.923 & 0.919 & 0.979 & 0.992 & 0.950 \\
\hline $\begin{array}{l}\text { E. coli } \\
\text { DSM50902 }\end{array}$ & 0.927 & 0.874 & 0.879 & 0.737 & 0.979 & 0.964 & 0.993 & 0.943 & 0.919 & 0.977 & 0.992 & 0.882 \\
\hline Average & 0.862 & 0.780 & 0.837 & 0.627 & 0.974 & 0.948 & 0.990 & 0.920 & 0.955 & 0.979 & 0.991 & 0.952 \\
\hline Std. Deviation & 0.057 & 0.161 & 0.090 & 0.205 & 0.010 & 0.056 & 0.007 & 0.051 & 0.035 & 0.013 & 0.010 & 0.035 \\
\hline
\end{tabular}

a n.d. not determined

Similarity values were occasionally quite low, as in the case of $B$. cereus which showed only $55.4 \%$ of similarities between PCR replicates and an overall similarity of $30.0 \%$. The low reproducibility is attributable to the low number of bands for this strain. BOX-PCR patterns were seldom richer than 15-20 bands and some of these bands were weak (Figure 2). A delicate step of BOX-PCR analysis is the gel staining with ethidium bromide and UV acquisition especially of weak bands. A disappearance of one band in a profile of 10 bands decreases the similarity of two identical profiles by $10 \%$. In the case of $B$. cereus, the average number of bands was only 6.8 and the absence of a weak band between two replicates affects the similarity by $15 \%$.

Polyacrylamide gels and silver staining gives better resolution of fragments with respect to agarose gel electrophoresis but is labour-intensive and can suffer a relatively low reproducibility due to the gel staining procedures. However it would be worth investigating the convenience of applying polyacrylamide gel electrophoresis for analysis of BOX-PCR patterns in comparison with F-BOX-PCR in terms of economic costs, time required in sample handling and overall reproducibility.

For all the strains that were tested, the use of BOX-A1R primer labelled with fluorescent chromophores affected the BOX-PCR profiles in agarose gel by decreasing the number of detectable bands (Figure 1 and Table 2); in case of $B$. cereus only one band was often visible for both HEX and 6-FAM labelled primers. Band pattern modifications were also noted in denaturing gradient gel electrophoresis (DGGE) for products labelled with 6-FAM dye in comparison with those non labelled [25]. Computerassisted analysis of agarose gel electrophoresis showed that patterns obtained with 6-FAM labelled primer were generally richer in bands than those obtained with the fluorophore HEX ( $\mathrm{p}<0.0004)$. A similar result was observed by Ranjard and collaborators [26], who found 6FAM primers giving the best total peak intensity in Automated rRNA Intergenic Spacer Analysis (ARISA).

\section{Reproducibility of capillary electrophoresis}

The F-BOX-PCR products labelled with HEX and 6-FAM were run twice in capillary electrophoresis. For all the strains tested, peak number obtained by using 6-FAM was significantly higher than DNA band numbers in agarose gel profiles obtained by BOX-PCR $\left(p<3 \times 10^{-6}\right)$ and 6 FAM-based F-BOX-PCR. 6-FAM peak profiles were confirmed to be generally richer than HEX patterns $(p<2 \times$ $10^{-7}$ ). The average number of peaks varied between 31.0 (strain DS3) and 72.0 (strain CI1-23) with very low relative standard deviations (between 0.0 and 2.0; Table 2). Altogether, F-BOX-PCR gave more informative patterns (1.9 to 12.0 times) than BOX-PCR, indicating that capillary electrophoresis detects at least two times more peaks than agarose gel stained with ethidium bromide. 6-FAM was more informative than HEX when comparing these FBOX-PCRs with standard BOX-PCR ( 1.3 to $11.3 ; p<3 \times$ $\left.10^{-8}\right)$. The richness of 6-FAM-based profiles is evident in Figure 2, in which an example of run for each strain tested is shown. Profiles were well characterized by a number of high, medium and above all, small peaks that were sometimes very important. For example in the profile of $B$. cereus 360 (Figure 2G) three high peaks were visible (5100 \pm 1800 units of fluorescence at $601 \mathrm{bp}, 3000 \pm 1700$ at 


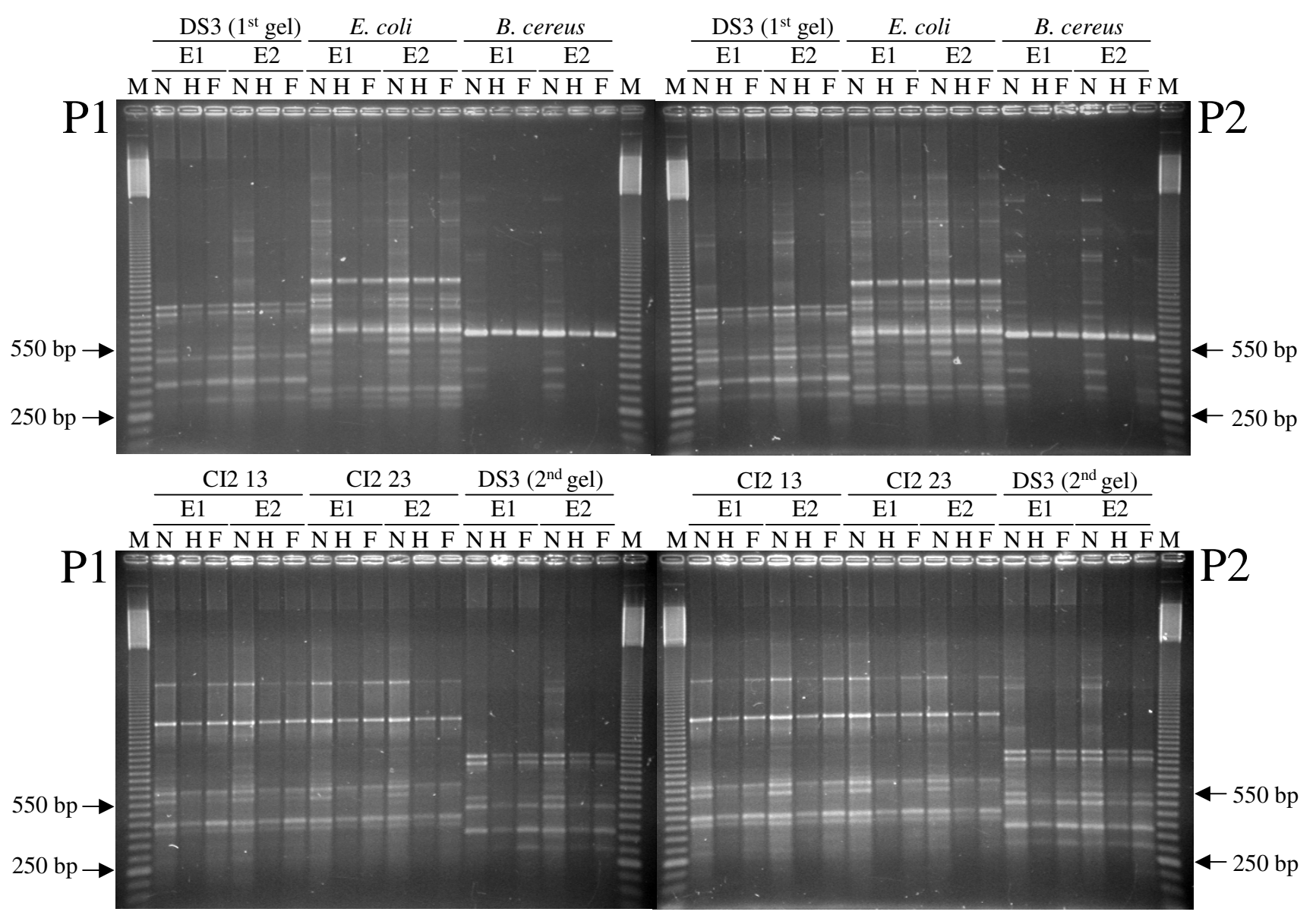

\section{Figure I}

Examples of agarose gels showing BOX-PCR obtained with the non fluorescent and fluorescent primers. Letter $\mathrm{N}$ indicates the non fluorescent primer, $\mathrm{H}$ indicates $\mathrm{HEX}$ primer, while $\mathrm{F}$ indicates 6-FAM primer. Letter $\mathrm{E}$ indicates the DNA extractions performed twice (EI and E2), while letter $\mathrm{P}$ indicates the PCR performed twice (PI and P2). For strain DS3, two diverse gels are shown. M, marker $50 \mathrm{bp}$.

893 bp and $4800 \pm 1900$ at 1555 bp), while other 33 were smaller than 200 units of fluorescence. The peak patterns of strains CI2-13, CI2-17 and CI2-23 were very similar with an average number of peaks of 47.3, 50.5 and 48.3 respectively. The comparison with their profiles in agarose gel amplified with the BOX-A1R primer (Figure 1) showed how the fluorescent system could reveal much more amplicons than the traditional agarose gel.

Since run characteristics along a capillary are nonlinear and most commercial size standards can present double peaks, there are greater uncertainties in sizing large DNA fragments. The Local Southern sizing method of Genescan software may improve the fragment sizing, generating the best-fit sizing curve. The software gives size in base pairs as a function of migration time of standard fragments. In our replicates we observed that up to $500 \mathrm{bp}$ the precision of separation in all samples was close to $\pm 0.5 \mathrm{bp}$, but over that, size precision constantly decreased reaching \pm 1 bp at $800 \mathrm{bp}, \pm 5$ bp at 1400 and \pm 10 bp at 2000 bp. Over 1500 $\mathrm{bp}$, the capability of separation of the $47 \mathrm{~cm}$-capillary provided with POP4 polymer is reduced heavily appreciably affecting the sizing process with peak size discrepancy of \pm 20 bp between replicated samples. Over $1300 \mathrm{bp}$, base peaks became wider and tended to merge as it can be noted in E. coli (Figure 2H). However, the precision of the region between 1300 and $2000 \mathrm{bp}$ in perfect conditions of run can be acceptable in comparison with agarose or polyacrylamide gels, since the seven peaks at 1700-2000 bp of the similar strains CI2-13, CI2-17 and CI2-23 can be easily aligned manually (Figure 2A, 2B, 2C). The problem of the discrepancy in sizing large fragments is reflected in the set up of the data matrix due to the size calling precision ( $\pm 0.01 \mathrm{bp})$. This uncertainty may cause F-BOX-PCR to appear less similar to each other, caused by splitting of peaks between adjacent combination windows [27]. Siz- 
Table 2: Number of fragments detected by BOX-PCR and F-BOX-PCR analysis using agarose and capillary electrophoresis separation and ratios between the number of fluorochrome-labeled fragments detected by capillary electrophoresis and the number of unlabeled fragments detected by agarose electrophoresisa.

\begin{tabular}{|c|c|c|c|c|c|c|c|c|c|c|}
\hline \multirow[t]{3}{*}{ Strain } & \multirow[t]{3}{*}{ DNA extraction ${ }^{\mathrm{a}}$} & \multirow[t]{3}{*}{$\mathrm{PCR}^{\mathrm{a}}$} & \multirow[t]{3}{*}{ Gel/Injection ${ }^{\mathrm{a}}$} & \multicolumn{5}{|c|}{ Number of observed fragment } & \multirow[t]{3}{*}{$\mathrm{RH}^{\mathrm{b}}$} & \multirow[t]{3}{*}{$\mathrm{RF}^{\mathrm{c}}$} \\
\hline & & & & \multicolumn{3}{|l|}{ On agarose gel } & \multicolumn{2}{|c|}{ On AbiPrism 310} & & \\
\hline & & & & Non fluorescent & HEX & 6-FAM & HEX & 6-FAM & & \\
\hline \multirow[t]{8}{*}{ B. cereus $\mathrm{BC} 360$} & 1 & 1 & 1 & 7 & 1 & 1 & 34 & 36 & 4.9 & 5.1 \\
\hline & 1 & 1 & 2 & 8 & n.d.e & n.d. & 34 & 36 & 4.3 & 4.5 \\
\hline & 1 & 2 & 1 & 3 & 1 & 1 & 34 & 36 & 11.3 & 12.0 \\
\hline & 1 & 2 & 2 & 3 & n.d. & n.d. & 34 & 36 & 11.3 & 12.0 \\
\hline & 2 & 1 & 1 & 10 & 1 & 5 & 34 & 36 & 3.4 & 3.6 \\
\hline & 2 & 1 & 2 & 7 & n.d. & n.d. & 34 & 36 & 4.9 & 5.1 \\
\hline & 2 & 2 & I & 7 & I & I & 33 & 36 & 4.7 & 5.1 \\
\hline & 2 & 2 & 2 & 5 & n.d. & n.d. & 33 & 36 & 6.6 & 7.2 \\
\hline \multirow[t]{4}{*}{$\mathrm{CII} 23$} & 1 & I & I & 13 & 8 & II & n.d. & 72 & n.a. & 5.5 \\
\hline & 1 & 1 & 2 & 13 & n.d. & n.d. & n.d. & 72 & n.a. & 5.5 \\
\hline & 1 & 2 & 1 & 16 & 6 & 10 & n.d. & 70 & n.a. & 4.4 \\
\hline & 1 & 2 & 2 & 13 & n.d. & n.d. & n.d. & 70 & n.a. & 5.4 \\
\hline \multirow[t]{8}{*}{$\mathrm{Cl} 2 \mathrm{I} 3$} & 1 & I & 1 & 9 & 5 & 6 & 34 & $4 I$ & 3.8 & 4.6 \\
\hline & 1 & 1 & 2 & 9 & n.d. & n.d. & 34 & 41 & 3.8 & 4.6 \\
\hline & 1 & 2 & I & 10 & 5 & 7 & 28 & 41 & 2.8 & 4.1 \\
\hline & 1 & 2 & 2 & 9 & n.d. & n.d. & 29 & 41 & 3.2 & 4.6 \\
\hline & 2 & 1 & 1 & 11 & 5 & 6 & 34 & 40 & 3.1 & 3.6 \\
\hline & 2 & I & 2 & 11 & n.d. & n.d. & 33 & 40 & 3.0 & 3.6 \\
\hline & 2 & 2 & I & 10 & 6 & 7 & 34 & 39 & 3.4 & 3.9 \\
\hline & 2 & 2 & 2 & 11 & n.d. & n.d. & 34 & 40 & 3.1 & 3.6 \\
\hline \multirow[t]{4}{*}{$\mathrm{Cl} 2 \mathrm{I7}$} & 1 & 1 & I & 10 & 7 & 10 & 26 & 50 & 2.6 & 5.0 \\
\hline & 1 & 1 & 2 & 9 & n.d. & n.d. & 26 & 49 & 2.9 & 5.4 \\
\hline & 1 & 2 & 1 & 18 & 4 & 10 & 27 & 52 & 1.5 & 2.9 \\
\hline & 1 & 2 & 2 & 13 & n.d. & n.d. & 26 & 51 & 2.0 & 3.9 \\
\hline \multirow[t]{8}{*}{$\mathrm{Cl} 223$} & 1 & 1 & 1 & 8 & 4 & 5 & 44 & 49 & 5.5 & 6.1 \\
\hline & 1 & 1 & 2 & 12 & n.d. & n.d. & 44 & 49 & 3.7 & 4.1 \\
\hline & 1 & 2 & 1 & 10 & 6 & 7 & 44 & 48 & 4.4 & 4.8 \\
\hline & 1 & 2 & 2 & 11 & n.d. & n.d. & 44 & 48 & 4.0 & 4.4 \\
\hline & 2 & 1 & I & 11 & 4 & 6 & 45 & 49 & 4.1 & 4.5 \\
\hline & 2 & 1 & 2 & 11 & n.d. & n.d. & 45 & 49 & 4.1 & 4.5 \\
\hline & 2 & 2 & 1 & 9 & 4 & 6 & 43 & 47 & 4.8 & 5.2 \\
\hline & 2 & 2 & 2 & 12 & n.d. & n.d. & 44 & 47 & 3.7 & 3.9 \\
\hline \multirow[t]{4}{*}{ CO2 33} & 1 & 1 & I & 12 & 3 & 5 & n.d. & 46 & n.a. & 3.8 \\
\hline & 1 & 1 & 2 & 10 & n.d. & n.d. & n.d. & 46 & n.a. & 4.6 \\
\hline & 1 & 2 & 1 & 9 & 3 & 5 & n.d. & 45 & n.a. & 5.0 \\
\hline & 1 & 2 & 2 & 11 & n.d. & n.d. & n.d. & 45 & n.a. & 4.1 \\
\hline \multirow[t]{8}{*}{ DS3 } & 1 & 1 & I & 14 & 6 & 7 & 35 & 34 & 2.5 & 2.4 \\
\hline & 1 & 1 & 2 & 13 & 6 & 6 & 35 & 34 & 2.7 & 2.6 \\
\hline & 1 & 2 & 1 & 7 & 5 & 7 & 33 & 34 & 4.7 & 4.9 \\
\hline & 1 & 2 & 2 & 6 & 4 & 5 & 33 & 34 & 5.5 & 5.7 \\
\hline & 2 & 1 & 1 & 16 & 6 & 8 & 34 & 30 & 2.1 & 1.9 \\
\hline & 2 & 1 & 2 & 13 & 6 & 7 & 33 & 31 & 2.5 & 2.4 \\
\hline & 2 & 2 & I & 13 & 6 & 7 & 33 & 32 & 2.5 & 2.5 \\
\hline & 2 & 2 & 2 & 8 & 6 & 6 & 33 & 32 & 4.1 & 4.0 \\
\hline E. coli DSM50902 & 1 & 1 & 1 & 19 & 10 & 13 & 26 & 57 & $\mathrm{I} .4$ & 3.0 \\
\hline & 1 & 1 & 2 & 17 & n.d. & n.d. & 26 & 57 & 1.5 & 3.4 \\
\hline & 1 & 2 & 1 & 18 & 3 & 9 & 24 & 57 & 1.3 & 3.2 \\
\hline & 1 & 2 & 2 & 14 & n.d. & n.d. & 25 & 57 & 1.8 & 4.1 \\
\hline & 2 & 1 & 1 & 19 & 8 & 14 & 26 & 58 & 1.4 & 3.1 \\
\hline & 2 & 1 & 2 & 16 & n.d. & n.d. & 26 & 57 & 1.6 & 3.6 \\
\hline & 2 & 2 & I & 15 & 9 & 15 & 26 & 60 & 1.7 & 4.0 \\
\hline & 2 & 2 & 2 & 15 & n.d. & n.d. & 26 & 60 & 1.7 & 4.0 \\
\hline
\end{tabular}


Table 2: Number of fragments detected by BOX-PCR and F-BOX-PCR analysis using agarose and capillary electrophoresis separation and ratios between the number of fluorochrome-labeled fragments detected by capillary electrophoresis and the number of unlabeled fragments detected by agarose electrophoresisa. (Continued)

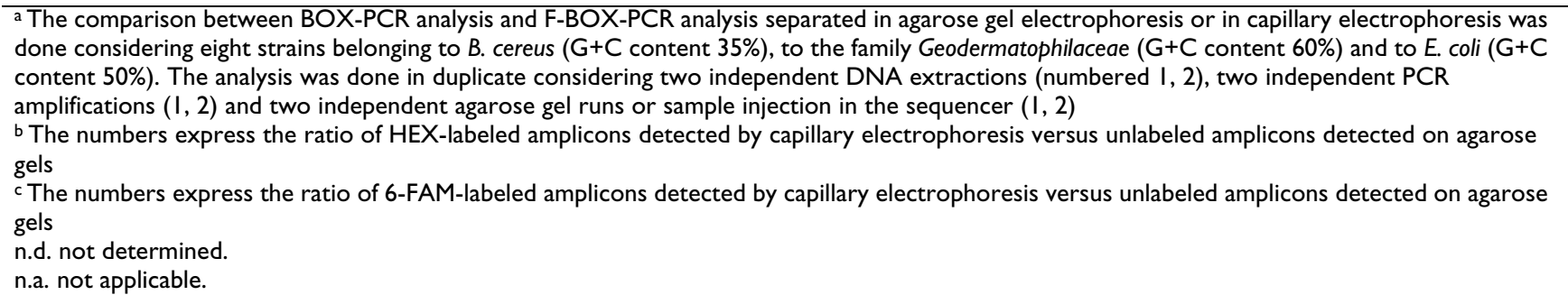

ing interpolation of large peaks beyond 1000 bp could be improved by an improvement of polymers used in fragment separation or in innovative downstream matrix analysis. In spite of these uncertainties, the overall percentage of similarity of replicated analyses for 6-FAMbased F-BOX-PCR was $95.2 \pm 3.5 \%$ (Table 1). As observed for agarose gels, the reproducibility of the technique is mainly affected by different DNA extractions and by different PCR amplifications than by capillary separation (Table

\section{F-BOX-PCR typing of M. multiseptatus from different stone microsites}

We used F-BOX-PCR for analyzing bacterial endemisms on the surface of three microsites of a highly biodeteriored calcarenite stone characterized by a relatively high rate of erosion due to rainwater, saltiness and wind. We previously found that this stone was heavily colonized by actinobacteria of the family Geodermatophilaceae, but typing with standard BOX-PCR failed to find clear relation between isolates and the microsites where they came from [23] despite these microsites were characterized by different colours and types of alterations (pittings, patinas, etc.).

We compared F-BOX-PCR with BOX-PCR, by analyzing with the two methods, 29 strains of $M$. multiseptatus isolated from the surface of three different microsites on the stones (microsites A, C and D). The number of bands detected by BOX-PCR were between 5 (strains AS4 and AS10) and 17 (strain Cag100) with an average of 10.3. Band size was between 250 and 2500 bp. UPGMA tree failed to clearly cluster strains on the basis of the microsite of isolation (Figure 3A). The similarity of groups was between 15 and $70 \%$. The comparison between the cophenetic similarity matrix and the original similarity matrix done with the Mantel's test gave a productmoment correlation of 0.68 , a very low fit value that do not make UPGMA output significant. F-BOX-PCR of these strains gave between 25 (AS12) and 49 (DS32) peaks with an average of 37.1. Peak size was between 150 and 1978 bp. The average height of the peaks was 310 units of fluorescence. Strains were grouped in the UPGMA tree accord- ing to the microsite of isolation (Figure 3B). Strains isolated from microsite A clustered in groups A and B, with an overall similarity of $11 \%$. Strains from microsite $\mathrm{C}$ were segregated in cluster $\mathrm{E}$ with most of the strains with a similarity of $9 \%$ and cluster F including strains Cag92 and Cag93 with a similarity of 38\%. Strains of microsite D clustered in one group (D) with $14 \%$ similarity, while strain DS32, although in relation with cluster D, appeared to be separated. The coefficients of similarity were lower than the BOX-PCR tree due to the number of peaks, 3.6 times higher than bands in the agarose gels. A very high product-moment correlation (0.96) characterized F-BOXPCR tree. Since clusters of Figure 3B were constituted by strains of homogeneous microsite origin, Pearson's correlation between sample location and genomic clusters shown in UPGMA tree was 1.00 .

\section{F-BOX-PCR typing of S. thermophilus isolates from different source in Georgia}

For evaluating if F-BOX-PCR can discriminate bacterial population on a geographical scale, the bacterial diversity of 45 strains of $S$. thermophilus isolated from the Georgian yoghurt Matsoni [24] produced in 34 different farms was studied (Table 3 ).

The number of bands detected by BOX-PCR were between 2 (for strain 3278) and 10 (strain 3238) with an average of 7.5 bands and size was between 250 and 2000 bp. Although some homogeneous groups were detectable in UPGMA tree (Figure 4A), cluster analysis failed to clearly group strains on the basis of the geographical origin of Matsoni $\left(\mathrm{r}=0.59, P=2 \times 10^{-5}\right)$. The similarity of groups was between 33 and 100\%. Five clusters included strains with identical BOX-PCR patterns, although strains were isolated from different regions in Georgia. Comparison between the cophenetic similarity matrix and the original similarity matrix done with the Mantel's test gave a product-moment correlation of 0.94, a very high fit value related to the relative low number of bands in the agarose gel and the high number of identical patterns.

F-BOX-PCR of the same strains gave between 11 (strain 3211 ) and 28 (strains 3232 and 3276) peaks with an aver- 


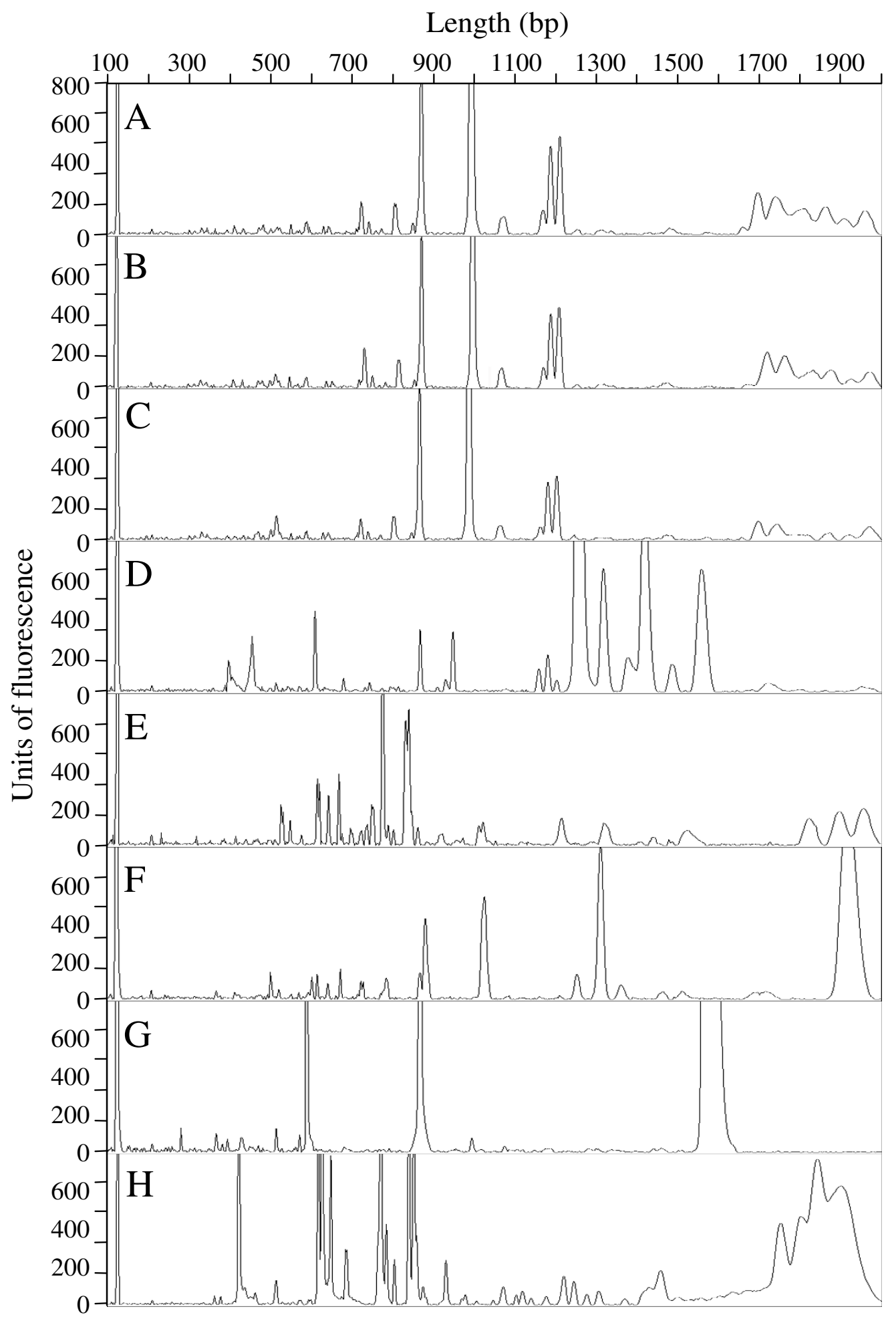

Figure 2

Examples of F-BOX-PCR electropherograms after analysis with Genescan software. Legend of letters: A. Blastococcus sp. $\mathrm{Cl} 2$ 13; B. Blastococcus sp. Cl2 17; C. Blastococcus sp. Cl2 23; D. Blastococcus sp. ClI 23; E. Modestobacter sp. CO2 33; F. Modestobacter sp. DS3; G. B. cereus 360. H. E. coli DSM50902. 

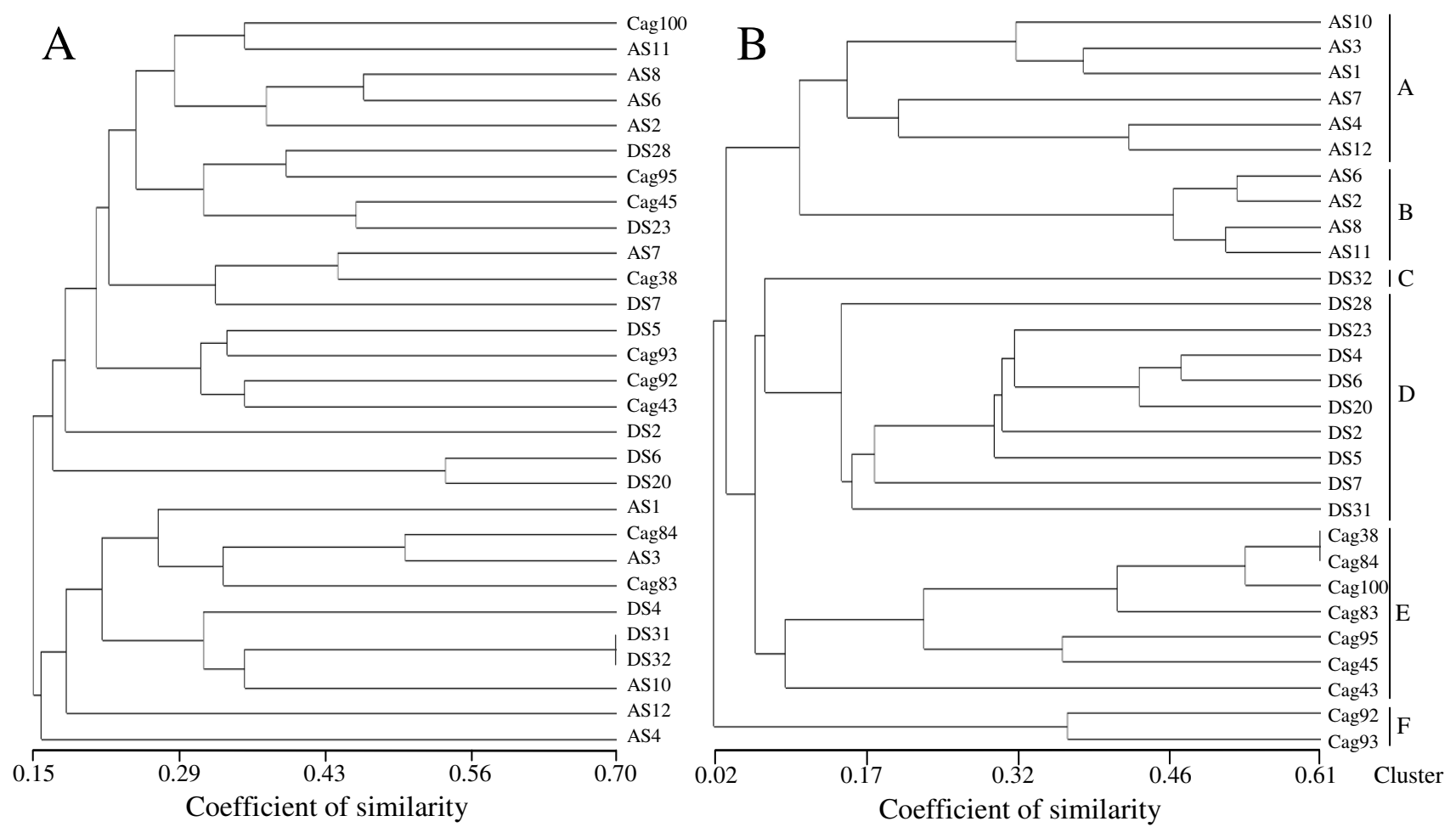

Figure 3

Similarity UPGMA trees of BOX-PCR patterns (A) and F-BOX-PCR patterns (B) of 29 bacterial strains belonging to Modestobacter sp. isolated from three different microsites of an altered carbonatic stone wall in the old city of Cagliari. The UPGMA tree originated by F-BOX-PCR was divided into 6 clusters on the basis of Pearson's $r$ correlation value.

age of 22.2 and sizes between 119 and 539 bp. The average peak height was 285 fluorescence units. The similarity coefficients were lower than the BOX-PCR tree (from 23 to $89 \%$ ) as observed with the previous analysis of $\mathrm{M}$. $\mathrm{mul}$ tiseptatus, but it is explained by the number of peaks three times higher than the bands in the agarose gel. F-BOXPCR did not produce identical patterns among the strains, hence the diversity in the peak matrix increased. For this reason, although the product-moment correlation of FBOX-PCR tree was lower than in the agarose gel-derived UPGMA tree ( 0.88 vs. 0.94$)$, the fit of the analysis is still positive.

F-BOX-PCR clustered $S$. thermophilus strains in the UPGMA dendrogram according to the geographical origin of the product from which they were isolated $(\mathrm{r}=0.81, P$ $\left.=3 \times 10^{-11}\right)$. Most of the strains isolated from western Georgia were clustered in two groups (A and B in Figure 4B) with similarity of $54 \%$ (including strains collected between $41^{\circ} 48^{\prime} \mathrm{E}$ and $42^{\circ} 42^{\prime} \mathrm{E}$ ) and $46 \%$ (strains isolated between $42^{\circ} 37^{\prime} \mathrm{E}$ and $42^{\circ} 46^{\prime} \mathrm{E}$ ). Within group A, it is placed strain 3203 from Mtskaldidi, a place relatively close to Senaki area. Cluster $\mathrm{C}$ includes with a similarity of
$56 \%$ two subclusters ( $\mathrm{C} 1$ and $\mathrm{C} 2$ ) with an average similarity of about $70 \%$. Strains from the Black Sea coast (between $41^{\circ} 43^{\prime} \mathrm{E}$ and $41^{\circ} 48^{\prime} \mathrm{E}$ ) were grouped into C1, with two strains isolated from inner western Georgia ( 3235 and 3236, both from Senaki, $42^{\circ} 03^{\prime} \mathrm{E}$, close to the Black Sea coast). Subcluster C2 was mainly formed by strains isolated in the surrounding area of Tbilisi (between $44^{\circ} 44^{\prime} \mathrm{E}$ and $44^{\circ} 51^{\prime} \mathrm{E}$ ), plus strain 3252 isolated in Batumi. Cluster D was formed by strains collected from various farms located in the mountain area of Central Georgia. The remaining strains were grouped in two groups ( $\mathrm{E}$ and $\mathrm{F}$ ) characterized by an overall homogeneous geographical origin, although group $\mathrm{F}$ had a low strain similarity (26\%). Detrended Principal Coordinate Analysis was used to cluster UPGMA groups defined by FBOX-PCR with ecotypes determined from the geographical characteristics of sampling site (Figure 5). The resulting plot, representing the $58.0 \%$ of the total inertia, confirmed the correlation found in the UPGMA tree. For example, clusters $\mathrm{C} 2$ and $\mathrm{E}$ were close to the Tbilisi area $(T)$, as expected, since they were mostly formed by strains isolated from that region. Strong relationships were also found for groups A and B according to the western origin 
Table 3: Geographical origin and F-BOX-PCR cluster of Streptococcus thermophilus strains isolated from Matsoni.

\begin{tabular}{|c|c|c|c|c|c|}
\hline Strain & Sampling place & Longitude & Farm & Geographical areal & F-BOX-PCR cluster \\
\hline 3252 & Batumi & $41^{\circ} 38^{\prime} \mathrm{E}$ & 21 & Black Sea $(S)$ & $\mathrm{C} 2$ \\
\hline 3238 & Gantiadi & $41^{\circ} 43^{\prime} \mathrm{E}$ & 17 & Black Sea (S) & $\mathrm{Cl}$ \\
\hline 3240 & Gantiadi & $41^{\circ} 43^{\prime} \mathrm{E}$ & 18 & Black Sea (S) & $\mathrm{Cl}$ \\
\hline 3242 & Gantiadi & $41^{\circ} 43^{\prime} \mathrm{E}$ & 18 & Black Sea $(S)$ & $\mathrm{Cl}$ \\
\hline 3232 & Kobuleti & $41^{\circ} 47^{\prime} \mathrm{E}$ & 14 & Black Sea $(S)$ & $\mathrm{Cl}$ \\
\hline 3233 & Kobuleti & $41^{\circ} 47^{\prime} \mathrm{E}$ & 14 & Black Sea (S) & $\mathrm{Cl}$ \\
\hline 3248 & Perva & $41^{\circ} 48^{\prime} \mathrm{E}$ & 20 & Black Sea $(S)$ & $\mathrm{E}$ \\
\hline 3203 & Mtskaldidi & $41^{\circ} 48^{\prime} \mathrm{E}$ & 1 & Black Sea (S) & A \\
\hline 3245 & Oryabatumi & $41^{\circ} 48^{\prime} \mathrm{E}$ & 19 & Black Sea (S) & $\mathrm{Cl}$ \\
\hline 3202 & Senaki & $42^{\circ} 03^{\prime} \mathrm{E}$ & 16 & West Georgia (W) & $A$ \\
\hline 3235 & Senaki & $42^{\circ} 03^{\prime} \mathrm{E}$ & 15 & West Georgia (W) & $\mathrm{Cl}$ \\
\hline 3236 & Senaki & $42^{\circ} 03^{\prime} \mathrm{E}$ & 15 & West Georgia (W) & $\mathrm{Cl}$ \\
\hline 3217 & Kvitiri & $42^{\circ} 37^{\prime} \mathrm{E}$ & 10 & West Georgia (W) & B \\
\hline 3219 & Kvitiri & $42^{\circ} 37^{\prime} \mathrm{E}$ & 10 & West Georgia (W) & $\mathrm{F}$ \\
\hline 3206 & Kutaisi & $42^{\circ} 42^{\prime} \mathrm{E}$ & 6 & West Georgia (W) & $A$ \\
\hline 3207 & Kutaisi & $42^{\circ} 42^{\prime} \mathrm{E}$ & 6 & West Georgia (W) & A \\
\hline 3213 & Kutaisi & $42^{\circ} 42^{\prime} \mathrm{E}$ & 9 & West Georgia (W) & B \\
\hline 3221 & Godogani & $42^{\circ} 46^{\prime} \mathrm{E}$ & 11 & West Georgia (W) & B \\
\hline 3222 & Godogani & $42^{\circ} 46^{\prime} \mathrm{E}$ & 11 & West Georgia (W) & B \\
\hline 3225 & Godogani & $42^{\circ} 46^{\prime} \mathrm{E}$ & 12 & West Georgia (W) & C \\
\hline IIA & Zestaphoni & $43^{\circ} 00^{\prime} \mathrm{E}$ & 33 & Mountain area $(M)$ & $\mathrm{D}$ \\
\hline $12 \mathrm{~A}$ & Zestaphoni & $43^{\circ} 00^{\prime} \mathrm{E}$ & 34 & Mountain area $(M)$ & $\mathrm{D}$ \\
\hline 4B & Bakuriani & $43^{\circ} 3 I^{\prime} E$ & 38 & Mountain area $(M)$ & $\mathrm{D}$ \\
\hline $4 \mathrm{~A}$ & Bakuriani & $43^{\circ} 3 I^{\prime} E$ & 37 & Mountain area $(M)$ & $\mathrm{D}$ \\
\hline 3211 & Surami & $43^{\circ} 33^{\prime} \mathrm{E}$ & 8 & Mountain area $(M)$ & $\mathrm{F}$ \\
\hline 3212 & Surami & $43^{\circ} 33^{\prime} \mathrm{E}$ & 8 & Mountain area $(M)$ & $\mathrm{F}$ \\
\hline ID & Khashuri & $43^{\circ} 35^{\prime} \mathrm{E}$ & 36 & Mountain area $(M)$ & $\mathrm{D}$ \\
\hline IOB & Metekhi & $44^{\circ} 20^{\prime} \mathrm{E}$ & 42 & Mountain area $(M)$ & $\mathrm{D}$ \\
\hline $10 C$ & Metekhi & $44^{\circ} 20^{\prime} \mathrm{E}$ & 42 & Mountain area $(M)$ & $\mathrm{D}$ \\
\hline 3261 & Tskhneti & $44^{\circ} 38^{\prime} \mathrm{E}$ & 25 & Tbilisi area $(T)$ & $E$ \\
\hline $3 B$ & Tskhneti & $44^{\circ} 38^{\prime} \mathrm{E}$ & 39 & Tbilisi area $(T)$ & $\mathrm{D}$ \\
\hline 1720 & Mtskheta & $44^{\circ} 42^{\prime} \mathrm{E}$ & 44 & Tbilisi area $(T)$ & $\mathrm{D}$ \\
\hline 3263 & Tabakhmela & $44^{\circ} 44^{\prime} \mathrm{E}$ & 26 & Tbilisi area $(T)$ & $\mathrm{C} 2$ \\
\hline 3265 & Tabakhmela & $44^{\circ} 44^{\prime} \mathrm{E}$ & 27 & Tbilisi area $(T)$ & $\mathrm{C} 2$ \\
\hline 3266 & Tabakhmela & $44^{\circ} 44^{\prime} \mathrm{E}$ & 27 & Tbilisi area $(T)$ & $\mathrm{C} 2$ \\
\hline 3270 & Shiheligi & $44^{\circ} 46^{\prime} \mathrm{E}$ & 28 & Tbilisi area $(T)$ & $\mathrm{C} 2$ \\
\hline 3271 & Shiheligi & $44^{\circ} 46^{\prime} \mathrm{E}$ & 28 & Tbilisi area $(T)$ & $\mathrm{C}$ \\
\hline 3273 & Teleti & $44^{\circ} 5 I^{\prime} \mathrm{E}$ & 29 & Tbilisi area $(T)$ & $\mathrm{C} 2$ \\
\hline 3275 & Teleti & $44^{\circ} 5 I^{\prime} \mathrm{E}$ & 30 & Tbilisi area $(T)$ & $\mathrm{C} 2$ \\
\hline 3276 & Teleti & $44^{\circ} 5 I^{\prime} \mathrm{E}$ & 30 & Tbilisi area $(T)$ & $\mathrm{C} 2$ \\
\hline 3278 & Teleti & $44^{\circ} 5 I^{\prime} \mathrm{E}$ & 31 & Tbilisi area $(T)$ & $E$ \\
\hline 3279 & Teleti & $44^{\circ} 5 I^{\prime} E$ & 32 & Tbilisi area $(T)$ & $\mathrm{D}$ \\
\hline $5 B$ & Tsxvarichamia & $44^{\circ} 55^{\prime} \mathrm{E}$ & 40 & Mountain area $(M)$ & $\mathrm{D}$ \\
\hline $6 \mathrm{~A}$ & Gombori & $45^{\circ} \mathrm{I} 4^{\prime} \mathrm{E}$ & 41 & Mountain area $(M)$ & $D$ \\
\hline
\end{tabular}

I Four geographical areas were defined according to longitude and altitude of the sampling places. The Black Sea area $(S)$ includes farms located on the coast between longitudes $41^{\circ} 00 \mathrm{E}$ and $42^{\circ} 00 \mathrm{E}$. The West Georgia area $(\mathrm{W})$ includes farms between longitudes $42^{\circ} 00 \mathrm{E}$ and $43^{\circ} 00 \mathrm{E}$. The Tbilisi area $(T)$ includes farms between $44^{\circ} 00 \mathrm{E}$ and $45^{\circ} 00 \mathrm{E}$. The mountain area $(\mathrm{M})$ includes farms in a wide range of longitudes (from $43^{\circ} 00 \mathrm{E}$ to $45^{\circ} \mathrm{I} 4$ E), which having in common an altitude higher than $800 \mathrm{~m}$.

of their samples $(W)$, for $\mathrm{C} 1$ including strains originating from the Black Sea coast $(S)$ and, partially, for D, including isolates from the mountain area $(M)$.

\section{Conclusion}

Our study showed that a bacterial DNA fingerprinting technique that use automated procedures for DNA fragment separation could be an advantageous methodology to type and track microbial isolates and define endemisms in homogeneous environments where differential pressure is exerted by secondary (minor) environmental factors. In the case of M. multiseptatus, while standard BOXPCR failed to find a clear strain clustering on the basis of sampling site [23], F-BOX-PCR gave a very well defined grouping with a clear relation with the microsite of isolation. This indicated that the technique can highlight ende- 

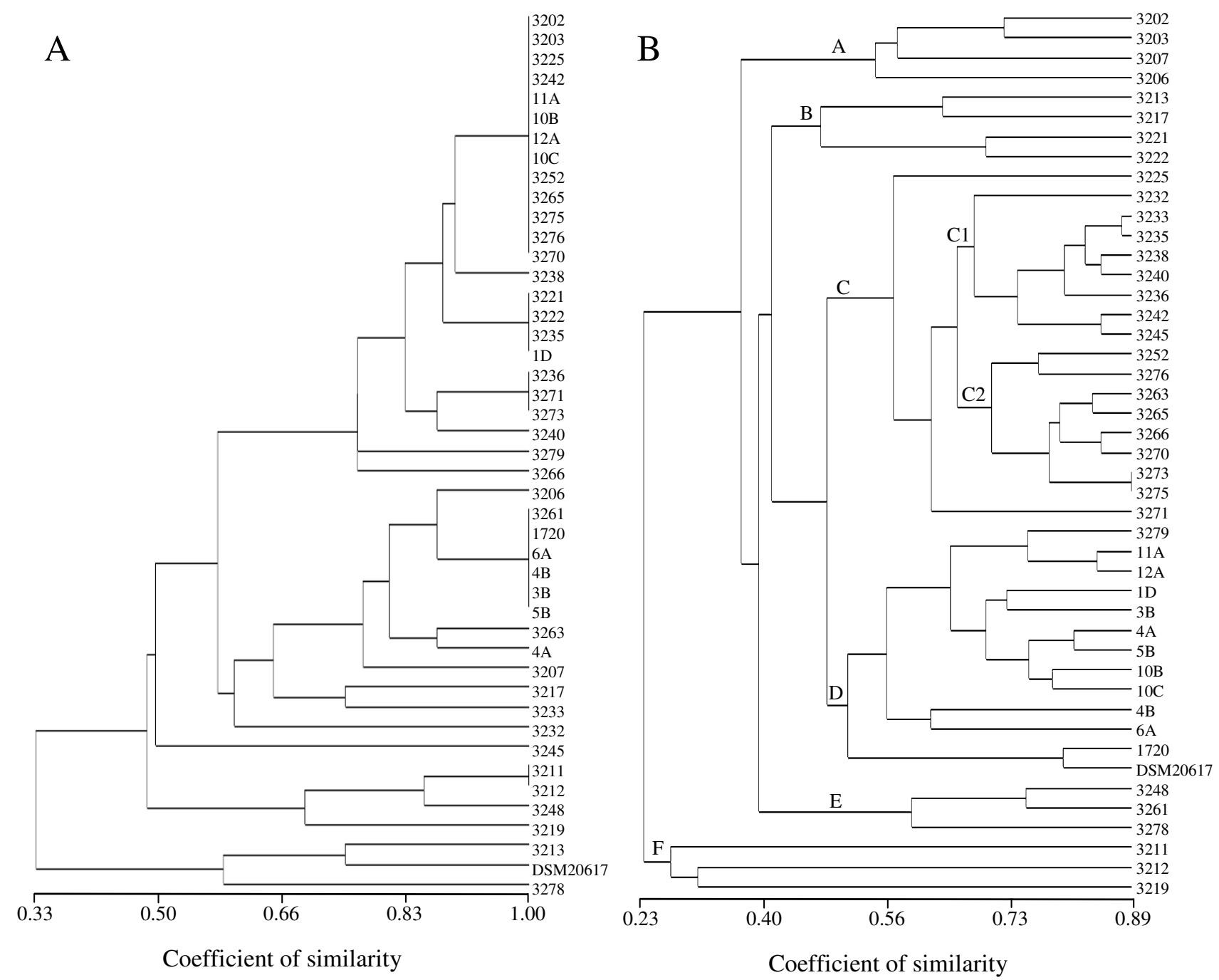

Figure 4

Similarity UPGMA trees of BOX-PCR patterns (A) and F-BOX-PCR patterns (B) of $\mathbf{4 5}$ bacterial strains belonging to $S$. thermophilus isolated from the typical yoghurt-like product Matsoni produced in 34 different farms in Georgia. The UPGMA tree originated by F-BOX-PCR described 6 clusters (A to F) and 2 subclusters $(\mathrm{Cl}$ and $\mathrm{C} 2)$, on the basis of Pearson's r correlation value.

misms in epilytic/endolytic environments, despite the environmental factors driving this endemism remain unknown and are still to be explored. In case of $S$. thermophilus, our data showed that F-BOX-PCR succeeded in defining a relation of strain types with the area of isolation, evidencing a geographical specificity. Despite the relative easiness, automated fingerprinting analysis is not yet much used in the industrial system, although the final output can be analyzed by rapid, efficient and computerized analyses. F-BOX-PCR can prove as an advantageous tool to routinely depict microbial communities, for instance, for typing isolates in food industry or in traditional and regional $[28,29]$ dairy products. F-BOX-PCR, coupled with other well-known automated techniques, could help in labelling food products with the P.D.O. (Protected Designation of Origin) and monitoring the related production chain. For example, F-BOX-PCR could be applied in parallel to Length Heterogeneity-PCR that was recently proposed as a rapid and precise method to characterise the lactic acid bacteria present in natural whey starters for the P.D.O. Grana Padano cheese and in maize silage $[30,31]$. 


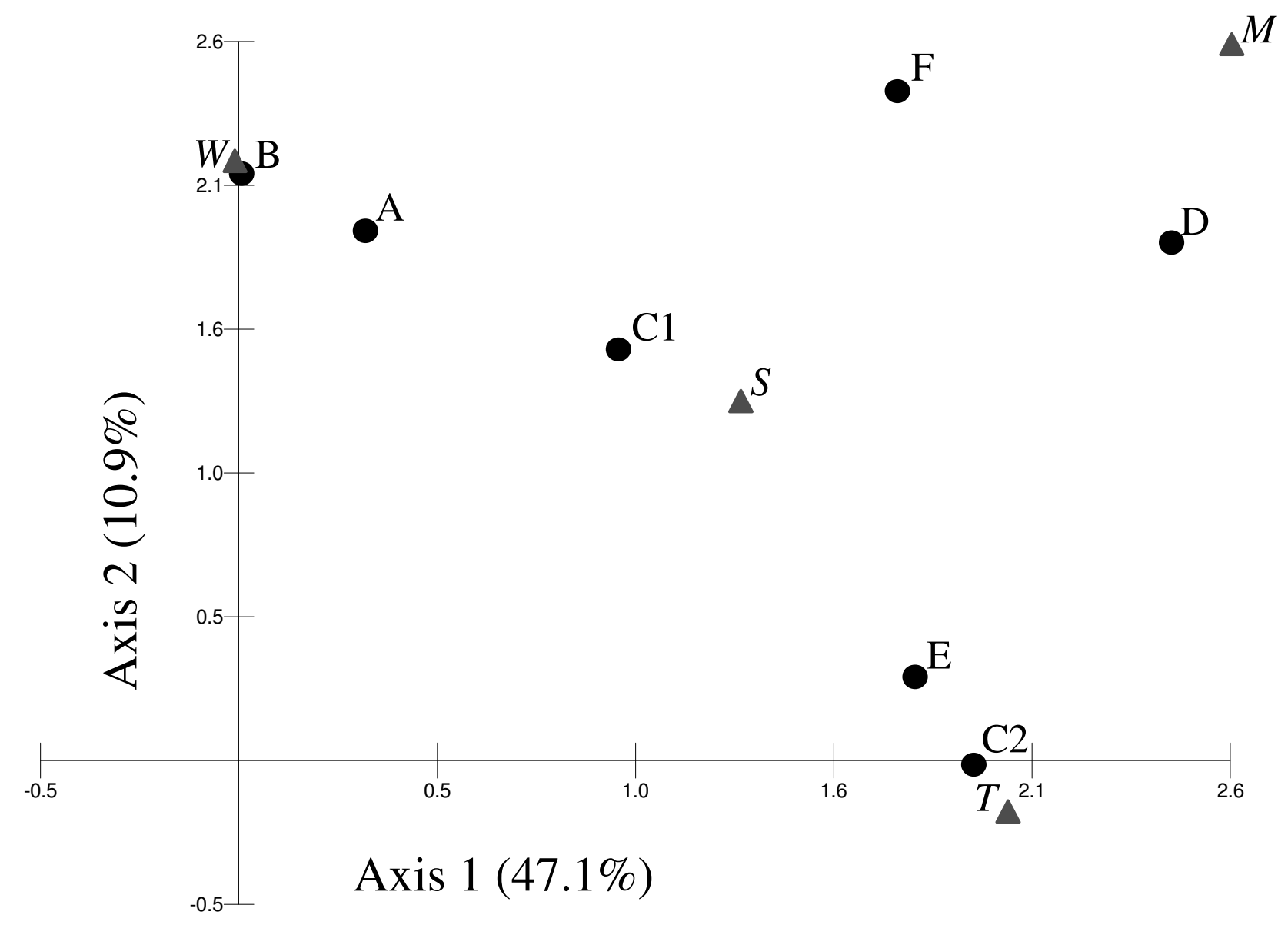

\section{Figure 5}

Detrended Principal Coordinate Analysis plot showing the relationships between the UPGMA groups defined by F-BOX-PCR and the ecotypes determined from the geographical characteristics of sampling sites. Letters (A to F) indicate the six F-BOX-PCR profile clusters as reported in Figure 4. Letters in italic indicated the geographical characteristics of the sampling sites, according to Table 3 (M, mountain area; S, Blak sea; $T$, Tbilisi area; W, West Georgia).

\section{Methods}

\section{Environmental samples and pure strains}

Bacterial strains used in this work belong to M. multiseptatus and to $S$. thermophilus species on the basis of $16 \mathrm{~S}$ rRNA gene analysis and species-specific PCR analysis targeted to lacZ gene [32] respectively. All strains isolated from Matsoni were also tested by carbohydrate fermentation profiles (API-20 Strep, Bio-Merieux). Strains belonging to M. multiseptatus were isolated from an ancient carbonatic wall of the city of Cagliari (Microsite C, Sardinia, Italy) [23]. The genotypes of these isolates attributed to the family Geodermatophilaceae have been previously studied by BOX-PCR [23]. In addition to these strains, other Geodermatophilaceae were isolated from two other microsites (A and D) of the same ancient wall, as previously described [23].
From 34 samples of home-made Matsoni, 45 strains belonging to $S$. thermophilus were isolated (Table 3). Matsoni samples were collected in local market or families in different cities or villages, from the eastern to the western part of Georgia. One $\mathrm{ml}$ of the sample was resuspended in $9 \mathrm{ml}$ sterilized $0.85 \% \mathrm{NaCl}$ solution and mixed thoroughly. Serial dilutions $\left(10^{-1}\right.$ to $\left.10^{-8}\right)$ were prepared and $0.1 \mathrm{ml}$ of appropriate dilution was spread in duplicate onto M17 agar plates. After incubation $\left(37^{\circ} \mathrm{C}, 24-48 \mathrm{~h}\right.$, aerobic conditions) strains were purified by streak plating and cultivated in M17 broth using lactose at the final concentration of $2 \%(\mathrm{w} / \mathrm{v})$. Stock cultures were stored in glycerol solution $(20 \%)$ at $-80^{\circ} \mathrm{C}$.

Modestobacter sp. DS3 and CO2-33, Blastococcus sp.CI1-23, CI2 17, CI2-13 and CI2-23, Escherichia coli DSM50902 
and Bacillus cereus 360 [17] were used as reference strains to test reproducibility of F-BOX-PCR.

\section{BOX-PCR and F-BOX-PCR}

DNA was extracted from the bacterial cultures as described elsewhere [33]. Genomic DNA integrity was checked by agarose gel electrophoresis and quantification was measured with a SmartSpec 3000 spectrophotometer (Biorad, Milan, Italy). BOX-PCR was performed by using the BOX-A1R primer [8] as previously reported [23] with $15 \mathrm{ng}$ of the DNA as template. The PCR product was run in agarose gels electrophoresis and banding patterns were acquired from the ethidium-bromide stained gels with GelDoc 2000 image system (Biorad) and stored on disk as 1sc files. The "rolling disk" background subtraction method was applied to each gel and a database containing all the gel images was created. Bands were automatically detected and normalized using the 50 bp DNA ladder (Pharmacia) as the molecular size marker. F-BOX-PCR was performed following the method of Urzì and collaborators [23] with the following modifications. Mixtures contained $1 \times$ PCR buffer (Pharmacia, Milan, Italy), $2 \mathrm{mM}$ $\mathrm{MgCl}_{2}, 0.1 \mathrm{mM}$ dNTPs, $0.8 \mu \mathrm{M}$ of each fluorescent primer, $5 \%$ of dimethylsulfoxide, $1.3 \mathrm{U}$ of Taq DNA polymerase (Pharmacia) and $15 \mathrm{ng}$ of genomic DNA in a final volume of $30 \mu \mathrm{l}$. Primer BOX-A1R was labelled alternatively with 6-FAM (6-carboxyfluorescein) or HEX (6-carboxyhexafluorescein) at their $5^{\prime}$ end. Reactions were denatured at $94^{\circ} \mathrm{C}$ for $5 \mathrm{~min}$, subjected to 35 cycles of $94^{\circ} \mathrm{C}$ for $1 \mathrm{~min}$, $45^{\circ} \mathrm{C}$ for $1 \mathrm{~min}$ and $72^{\circ} \mathrm{C}$ for $2 \mathrm{~min}$. A final extension at $72^{\circ} \mathrm{C}$ for $10 \mathrm{~min}$ was added. The amount of PCR products were estimated on agarose gel and $3 \mu \mathrm{l}$ of each product were added to $15 \mu$ of deionized formamide, containing $1 \mu \mathrm{l}$ of 2500 ROX-labelled internal size standard (Applied Biosystems, Monza, Italy). Samples were denatured at $95^{\circ} \mathrm{C}$ for $10 \mathrm{~min}$ and rapidly put into ice for $7 \mathrm{~min}$. FBOX-PCR fragments were loaded on a 310 Abi Prism capillary electrophoresis in denaturing conditions using POP4 running polymer and a $47 \mathrm{~cm} \times 50 \mu \mathrm{m}$ capillary. Samples were run for $60 \mathrm{~min}$ at $15 \mathrm{kV}$. The injection time of each sample was $5 \mathrm{sec}$ at $15 \mathrm{kV}$. Data were analyzed with Genescan 3.1.2 software (Applied Biosystems): a threshold of 50 fluorescent units was used, corresponding to 2 times the highest peak value detected during the negative control run, and sizing was done with the Local Southern Method and light data smoothing. If the baseline varied inconsistently, the sample was rerun.

\section{Reproducibility of F-BOX-PCR}

Genomic DNA was extracted by two different operators and the subsequent PCRs with the agarose gel runs were executed by two different operators as well. Each PCR was loaded twice in the sequencer. Each sample loaded was subjected to two separate injections. Duplicate injections of each sample of the Abi Prism 310 were analyzed for replicated peaks. Peaks present in only one duplicate were discarded, since they probably are salt spikes of the POP4 running polymer (Genescan Reference Guide). Moreover, peaks shorter than 3000 data points were not analyzed, since they are formed by fluorescent primers and primer dimers.

\section{Statistical analysis}

Average number of bands or peaks and standard deviation were performed. Comparisons between band or peak number and between efficiency values of each technique were performed with the Student's t test. The band and peak matrices corresponding to the BOX-PCR and F-BOXPCR profiles were subjected to a cluster analysis. A binary $0 / 1$ matrix was created basing on the absence or presence of DNA bands or peaks. Pairwise distances were calculated with the SimQual function of the NTSYSpc 2.01 computer program (Applied Biostatistics Inc., USA) by employing the Jaccard's coefficient for two-state data and strain clustering was performed by the UPGMA analysis [34]. The significance of the resulting tree was checked by comparing the original similarity matrix with the cophenetic similarity matrix by using the Mantel test. The correlation between the geographical origin of Matsoni from which the strains were isolated and the subclusters which were identified by the UPGMA analysis, was done with both the Pearson's $r$ correlation test using the PAST software [35] and a Detrended Principal Coordinate Analysis using the MVSP 3.13n software (Kovach Computing Services, Anglesey, UK). Data scores were detrended and no species weighting was applied. The number of axes to be extracted was calculated by Gittman-Kaiser's familiar eigenvalue rule [36].

\section{Authors' contributions}

LB and DD conceived the study design, coordinated the overall work and participated in writing the manuscript. LB: carried out all the statistical analyses, and participated in molecular biology experiments. MG: carried out isolation and identification of bacterial strains from stone surface. DM: carried out identification of $S$. thermophilus strains. IT: carried out BOX-PCR and F-BOX-PCR setup experiments and participated in writing the manuscript. IM: carried out F-BOX-PCR experiments on $S$. thermophilus strains. SB, NC, FC and MM participated in BOX-PCR and F-BOX-PCR of the bacterial isolates. All authors read and approved the final manuscript.

\section{Acknowledgements}

This work was supported by the EU project TRANSBAC QLK3-CT-200I02242 (5th RTD Program) and the Italian FIRB project "Strategy to improve plant productivity under water stress conditions", funded by the Italian Ministry of University and Research. DD acknowledges support from the Fondazione dei Diritti Genetici, funded by Fondazione Cariplo, Italy. The authors thank Deborah Colnago and Antonio Zaccaria for excellent labo- 
ratory assistance. The manuscript was edited for language by Sachin Bachate.

\section{References}

I. Carson CA, Shear BL, Ellersieck MR, Schnell JD: Comparison of ribotyping and Repetitive Extragenic Palindromic-PCR for identification of fecal Escherichia coli from humans and animals. Appl Environ Microbiol 2003, 69:1836-1839.

2. Daffonchio D, Raddadi N, Merabishvili M, Cherif A, Carmagnola L, Brusetti L, Rizzi A, Chanishvili N, Visca P, Sharp R, Borin S: Strategy for identification of Bacillus cereus and Bacillus thuringiensis strains closely related to Bacillus anthracis. Appl Environ Microbiol 2006, 72:|295-130|

3. Fajardo-Cavazos P, Nicholson W: Bacillus endospores isolated from granite: close molecular relationships to globally distributed Bacillus spp. from endolithic and extreme environments. Appl Environ Microbiol 2006, 72:2856-2863.

4. Ferris MJ, Kuhl M, Wieland A, Ward DM: Cyanobacterial ecotypes in different optical microenvironments of a 68 degrees $C$ hot spring mat community revealed by I6S-23S rRNA internal transcribed spacer region variation. Appl Environ Microbiol 2003, 69:2893-2898.

5. Oda Y, Star B, Huisman LA, Gottschal JC, Forney LJ: Biogeography of the purple nonsulfur bacterium Rhodopseudomonas palustris. Appl Environ Microbiol 2003, 69:5 I86-5I9I.

6. Bent SJ, Gucker CL, Oda Y, Forney LJ: Spatial distribution of Rhodopseudomonas palustris ecotypes on a local scale. Appl Environ Microbiol 2003, 69:5192-5197.

7. Versalovic J, Koeuth T, Lupski JR: Distribution of repetitive DNA sequences in eubacteria and application to fingerprinting of bacterial genomes. Nucleic Acids Res 1991, 19:6823-683 I.

8. Versalovic J, Schneider M, De Bruijn FJ, Lupski JR: Genomic fingerprinting of bacteria using repetitive sequence-based polymerase chain reaction. Methods Mol Cell Biol 1994, 5:25-40.

9. Koeuth T, Versalovic J, Lupski JR: Differential subsequence conservation of interspersed repetitive Streptococcus pneumoniae BOX elements in diverse bacteria. Genome Res 1995, 5:408-418.

10. Martin B, Humbert O, Camara M, Guenzi E, Walker J, Mitchell T, Andrew P, Prudhomme M, Alloing G, Hakenbeck R, Morrison DA, Boulnois G], Claverys JP: A highly conserved repeated DNA element located in the chromosome of Streptococcus pneumoniae. Nucleic Acids Res 1992, 20:3479-3483.

II. Van Belkum A, Scherer S, Van Alphen L, Verbrugh H: Shortsequence DNA repeats in prokaryotic genomes. Microbiol Mol Biol Rev 1998, 62:275-293.

12. Chmielewski R, Wieliczko A, Kuczkowski M, Mazurkiewicz M, Ugorski M: Comparison of ITS profiling, REP- and ERIC-PCR of Salmonella enteritidis isolates from Poland. J Vet Med 2002, 49:163-168

13. Niemann S, Pühler A, Ticky HV, Simon R, Selbitschka W: Evaluation of the resolving power of three different DNA fingerprinting methods to discriminate among isolates of a natural Rhizobium meliloti population. J Appl Microbiol 1997, 82:477-484.

14. Olive DM, Bean P: Principles and applications of methods for DNA-based typing of microbial organisms. J Clin Microbiol I999, 37:1661-1669.

I5. Kang HP, Dunne WM: Stability of repetitive-sequence PCR patterns with respect to culture age and subculture frequency. J Clin Microbiol 2003, 4I:2694-2696.

16. Ni Tuang F, Rademaker JLW, Alocilja EC, Louws FJ, de Bruijn FJ Identification of bacterial rep-PCR genomic fingerprints using a backpropagation neural network. FEMS Microbiol Lett 1999, I 77:249-256.

17. Cherif A, Brusetti L, Borin S, Rizzi A, Boudabous A, Khyami-Horani $H$, Daffonchio D: Genetic relationship in the "Bacillus cereus group" by rep-PCR fingerprinting and sequencing of a Bacillus anthracis-specific rep-PCR fragment. J Appl Microbiol 2003, 94: II08-III9.

18. Dombek PE, Johnson LK, Zimmerley ST, Sadowsky MJ: Use of repetitive DNA sequences and the PCR to differentiate Escherichia coli isolates from human and animal sources. Appl Environ Microbiol 2000, 66:2572-2577.

19. Landa BB, Mavrodi OV, Raaijmakers JM, McSpadden Gardener BB, Thomashow LS, Weller DM: Differential ability of genotypes of 2,4-diacetylphloroglucinol-producing Pseudomonas fluorescens strains to colonize the roots of pea plants. Appl Environ Microbiol 2002, 68:3226-3237.

20. Singh DV, Matte MH, Matte GR, Jiang S, Sabeena F, Shukla BN, Sanyal SC, Huq A, Colwell RR: Molecular analysis of Vibrio cholerae O I, OI39, non-OI, and non-OI39 strains: clonal relationship between clinical and environmental isolates. Appl Environ Microbiol 2001, 67:910-921.

21. Versalovic J, Kapur V, Koeuth T, Mazurek GH, Whittam TS, Musser JM, Lupski JR: DNA fingerprinting of pathogenic bacteria by fluorophore-enhanced repetitive sequence-based polymerase chain reaction. Arch Pathol Lab Med 1995, I I 9:23-29.

22. Del Vecchio VG, Petroziello JM, Gress MJ, McClesky FK, Melcher GP, Crouch HK, Lupski JR: Molecular genotyping of methicillinresistant Staphylococcus aureus via fluorophore-enhanced repetitive-sequence PCR. J Clin Microbiol 1995, 33:2 I4I-2 I 44.

23. Urzì C, Brusetti L, Salamone P, Sorlini C, Stackebrandt E, Daffonchio $D$ : Biodiversity of Geodermatophilaceae isolated from altered stones and monuments in the Mediterranean basin. Environ Microbiol 200I, 3:47I-479.

24. Chanishvili N: Identification of the lactic acid bacterial cultures isolated from the samples of the caucasian Matsoni. Proc Georgian Acad Sci Biol Ser 200 I, 27:91-95.

25. Neufeld JD, Mohn WW: Fluorophore-labelled primers improve the sensitivity, versatility, and normalization of denaturing gradient gel electrophoresis. Appl Environ Microbiol 2005, 7 I :4893-4896.

26. Ranjard L, Poly F, Lata JC, Mougel C, Thioulouse J, Nazaret S: Characterization of bacterial and fungal soil communities by automated ribosomal intergenic spacer analysis fingerprints: biological and methodological variability. Appl Environ Microbiol 2001, 67:4479-4487.

27. Hewson I, Fuhrman JA: Richness and diversity of bacterioplankton species along an estuarine gradient in Moreton Bay, Australia. Appl Environ Microbiol 2004, 70:3425-3433.

28. Soomro AH, Masud T: Selection of yoghurt starter culture from indigenous isolates of Streptococcus thermophilus and Lactobacillus delbrueckii subsp. bulgaricus on the basis of technological properties. Ann Microbiol 2008, 58:67-7l.

29. Ouzari H, Najjari A, Amairi H, Gtari M, Hassen A, Boudabous A Comparative analysis of Lactococcus lactis bacteriocins and preliminary characterisation of a new proteinase $K$ resistant lactococcin member. Ann Microbiol 2008, 58:83-88.

30. Brusetti L, Borin S, Mora D, Rizzi A, Raddadi N, Sorlini C, Daffonchio $D$ : Usefulness of length heterogeneity-PCR for monitoring lactic acid bacteria succession during maize ensiling. FEMS Microbiol Ecol 2006, 56: I54-164.

31. Lazzi C, Rossetti L, Zago M, Neviani E, Giraffa G: Evaluation of bacterial communities belonging to natural whey starters for Grana Padano cheese by length heterogeneity-PCR. J Appl Microbiol 2004, 94:48I-490.

32. Lick S, Keller M, Bokelmann W, Jochem Heller K: Rapid identification of Streptococcus thermophilus strains. Syst Appl Microbiol 1996, 19:74-77.

33. Ausubel FM, Brent R, Kingston RE, Moore DD, Seidman JG, Smith JA, Struhl K: Current protocols in molecular biology USA: John Wiley and Sons; 1994

34. Daffonchio D, Cherif A, Borin S: Homoduplex and heteroduplex polymorphisms of the amplified ribosomal I6S-23S internal transcribed spacers describe genetic relationships in the "Bacillus cereus group". Appl Environ Microbiol 2000, 66:5460-5468.

35. Hammer $\varnothing$, Harper DAT, Ryan PJ: PAST: Paleontological Statistics Software Package for Education and Data Analysis. Palaeontologia Electronica 200I, 4: I-9.

36. Jackson J: A User's Guide to Principal Components New York: John Wiley \& Sons; 1991 . 